Article

\title{
Environmental and Economic Impact of the Antifreeze Agents in Geothermal Heat Exchangers
}

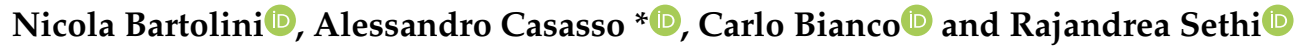 \\ Department of Environment, Land and Infrastructure Engineering, Politecnico di Torino, 10129 Torino, Italy; \\ nicola.bartolini@polito.it (N.B.); carlo.bianco@polito.it (C.B.); rajandrea.sethi@polito.it (R.S.) \\ * Correspondence: alessandro.casasso@polito.it; Tel.: +39-3204213886
}

Received: 12 September 2020; Accepted: 27 October 2020; Published: 29 October 2020

\begin{abstract}
Borehole heat exchangers (BHEs) generally employ water-antifreeze solutions to allow working fluid temperatures to fall below $0{ }^{\circ} \mathrm{C}$. However, some local regulations have forbidden antifreeze additives (even non-toxic ones) to avoid groundwater pollution in case of pipe leakage. This paper presents a techno-economic and environmental analysis of four different fluids: propylene glycol at $25 \%$ and $33 \%$ weight concentrations, calcium chloride at $20 \%$ weight concentration $\left(\mathrm{CaCl}_{2}\right.$ $20 \%$ ), and pure water. Thermal loads from 36 case studies in six different climate zones are used to perform BHE sizing and compare the abovementioned fluids from the economic, operational, and environmental points of view. The economic analysis and the carbon footprint assessment are performed on a life cycle of 25 years considering the installation (BHE drilling, fluid) and operation (heat pump and ground-side circulation pump energy demand, fluid replacement) of the simulated GSHPs. Results highlight that using pure water as a heat carrier fluid is convenient for cooling-dominated buildings but, for heating-dominated buildings, this choice leads to a noticeable increase of the BHE needed length which is not compensated by the lower operational costs. On the other hand, avoiding the use of antifreeze additives generally leads to a reduction of the lifetime carbon footprint, with a few exceptions in very cold climates. $\mathrm{CaCl}_{2} 20 \%$ proves to be a good choice in most cases, both from the economic and the environmental points of view, as it allows a strong reduction of the installed BHE length in cold climates with a low additional cost and carbon footprint.
\end{abstract}

Keywords: borehole heat exchanger; ground source heat pump; heat carrier fluid; propylene glycol; calcium chloride; carbon footprint

\section{Introduction}

Ground source heat pumps (GSHPs) for heating and cooling of buildings are becoming more and more popular thanks to their low operational costs and to the increasing need to reduce anthropogenic greenhouse gas (GHG) emissions. The total number of GSHPs installed in Europe is of approximately 1.9 million units, with a yearly increase of $6.5 \%$ between 2012 and 2018 [1,2]. Sweden (with 10 million inhabitants only) leads the ranking with almost 600,000 installations, followed by Germany, France, Finland, and Switzerland [1].

The most diffused type of GSHP is equipped with Borehole Heat Exchangers (BHEs), i.e., boreholes with diameters of 15-20 cm and depths of 50-200 m, where a heat carrier fluid circulates through one (1U) or two (2U) U-pipe loops or, less frequently, into a loop composed of two coaxial pipes [3]. The heat carrier fluids circulating into the BHEs are generally water solutions of antifreeze additives. This allows BHEs to operate below $0{ }^{\circ} \mathrm{C}$, thus increasing the heat extraction per unit length and hence reducing the $\mathrm{BHE}$ length needed to cover the building's heating demand.

Currently, the most adopted antifreeze additives are mono propylene glycol (PG) and ethylene glycol (EG). For example, according to the BHE registry of Region Lombardia in Italy [4], PG is adopted 
as the antifreeze additive in $61 \%$ of the 4635 registered installations, whereas $29 \%$ of them use EG and $7 \%$ use pure water. Salts, like calcium chloride, are seldom used due to the risk of corrosion [3]. Ethanol was used in the past but fell into disuse due to flammability concerns. Methanol was used too, but it has been phased out due to its toxicity.

In recent years the use of pure water as a heat carrier fluid has increased and it is sometimes prescribed by public authorities [5-7] due to concerns on the environmental impact of the additive in the case of pipe leakage, i.e., toxic effects and groundwater geochemical alterations [5,8]. The toxicity of a substance is expressed as the threshold dose (supposedly assumed by a living being) below which adverse effects are not experimentally observed: the higher such threshold dose, the lower the toxicity. Methanol and EG are the most toxic additives, with an oral chronic reference dose (RfD) of $2 \mathrm{mg} /$ day per $\mathrm{kg}$ of weight, whereas PG is far less toxic ( $\mathrm{RfD}=20 \mathrm{mg} / \mathrm{kg} /$ day) [9]. Organic additives have a possible indirect impact represented by the redox alteration of groundwater, which may trigger the mobilization of heavy metals [10], as observed in several airports where these compounds are used as deicing agents [11,12]. On the other hand, calcium chloride has a negligible toxicity [13] and no groundwater potential chemical impact (in the case of a release into subsurface) other than an increase of $\mathrm{Ca}^{2+}$ and $\mathrm{Cl}^{-}$ions.

The use of antifreeze additives, which allow BHE temperatures to fall below $0{ }^{\circ} \mathrm{C}$, also implies the risk of cracking the geothermal grout due to freeze-thaw cycles [14,15], thus triggering the cross-contamination between aquifers [16]. The use of antifreeze additives has an impact on the life cycle costs of a GSHP as well. Firstly, the antifreeze represents a non-negligible additional installation cost. Secondly, organic compounds tend to degrade and hence a full replacement of glycol is needed every 3-5 years [17]. Moreover, the electricity demand of the ground-side circulation pump depends on the fluid viscosity (which increases with the antifreeze concentration) and on the flow rate applied [18,19]. Lastly, lowering fluid temperatures by using antifreeze leads to a reduction of the heat pump efficiency and, therefore, to an increase in the electricity demand of the heat pump.

The above-reported references reveal that the use of antifreeze additives for BHEs has several technical and environmental drawbacks, which can be avoided by using pure water. However, this solution becomes economically unfeasible if the resulting increase of the BHE length to be drilled is too large. An overall techno-economic and environmental analysis on the choice of the BHE fluids is still missing in the literature. The work presented in this paper aims at filling this gap. Earth Energy Designer (EED) software [20] was employed to size and simulate the operation of geothermal plants located in different climates, using as input the thermal loads relating to three types of buildings (houses, hotels and offices) and two types of thermal insulation [21]. With these results, the impact of the fluid choice was assessed in terms of installation costs, energy consumption of the heat pump and the ground-side circulation pump, and of the overall greenhouse gas emissions related to the installation and operation of the GSHP.

\section{Methods}

This section describes the methods adopted for the techno-economic and environmental analysis on four different BHE fluid options (PG25\% and $\mathrm{PG} 33 \%, \mathrm{CaCl}_{2} 20 \%$, and pure water). Section 2.1 presents the 36 input thermal loads used for the sizing of BHE fields: these loads are representative of three different building types with two different levels of building envelope insulation in six different climate zones. Section 2.2 describes how the BHE fields were sized according to the thermal loads, using the software Earth Energy Designer (EED). Section 2.3 describes how the electrical energy demand of the simulated geothermal systems was calculated, considering the two components-the heat pump and the ground-side circulation pump-whose operation is most affected by the choice of the heat carrier fluid. Section 2.4 presents how the results of BHE field sizing and energy demand calculations were used to assess life cycle costs, whereas Section 2.5 presents how the GHG emissions of the hypothesized configurations were estimated. 


\subsection{Input Thermal Loads}

The effect of choosing different heat carrier fluids strongly varies depending on the building type, the undisturbed ground temperature, and the usage profile which, in turn, depends on the climate and on the building type. Using or not an antifreeze additive in BHEs installed in a cold climate, and hence with a heating-dominated usage profile, is expected to have a much stronger impact on installation costs and system performance compared to a plant installed in a warmer climate. A wide range of usage profiles was considered, using thermal load data from a recent paper by Rivoire et al. (2018, [21]). This study was specifically addressed to GSHPs equipped with BHEs and analyzed thermal loads of six European cities representative of different climates, from the coldest to the warmest: Stockholm, Berlin, Belgrade, Bologna, Lisbon, and Seville. Climate data of these cities were used to perform the dynamic energy modelling of three different benchmark buildings (a hotel, a detached house and an office building) with two degrees of insulation: "high insulation" (typical of buildings complying with the present Italian legislation, see [22]) and "low insulation" (based on typical transmittance values typical of 1960 and reported in [23,24]). The heated/cooled surfaces of the buildings modelled are of $221 \mathrm{~m}^{2}$ for the detached house, $381 \mathrm{~m}^{2}$ for the office building, and $2840 \mathrm{~m}^{2}$ for the hotel. The thermal transmittance of external walls was set to $0.28 \mathrm{~W} \cdot \mathrm{m}^{2} \cdot \mathrm{K}^{-1}$ for the "high insulation" case and to $1.60 \mathrm{~W} \cdot \mathrm{m}^{2} \cdot \mathrm{K}^{-1}$ for the "low insulation case"; for the under-roof slab, transmittance values were set to $0.51 \mathrm{~W} \cdot \mathrm{m}^{2} \cdot \mathrm{K}^{-1}$ and $1.76 \mathrm{~W} \cdot \mathrm{m}^{2} \cdot \mathrm{K}^{-1}$, respectively; double-glazed windows were set for the "high insulation" case, with a transmittance of $1.43 \mathrm{~W} \cdot \mathrm{m}^{2} \cdot \mathrm{K}^{-1}$, whereas single-glazed windows (transmittance $1.60 \mathrm{~W} \cdot \mathrm{m}^{2} \cdot \mathrm{K}^{-1}$ ) were considered for the "low insulation" case. The yearly heating and cooling demands of the 36 modelled buildings are shown in Figure 1. The values of the overall monthly thermal loads and of the peak thermal loads are available in the Supplementary Materials (Table S1).
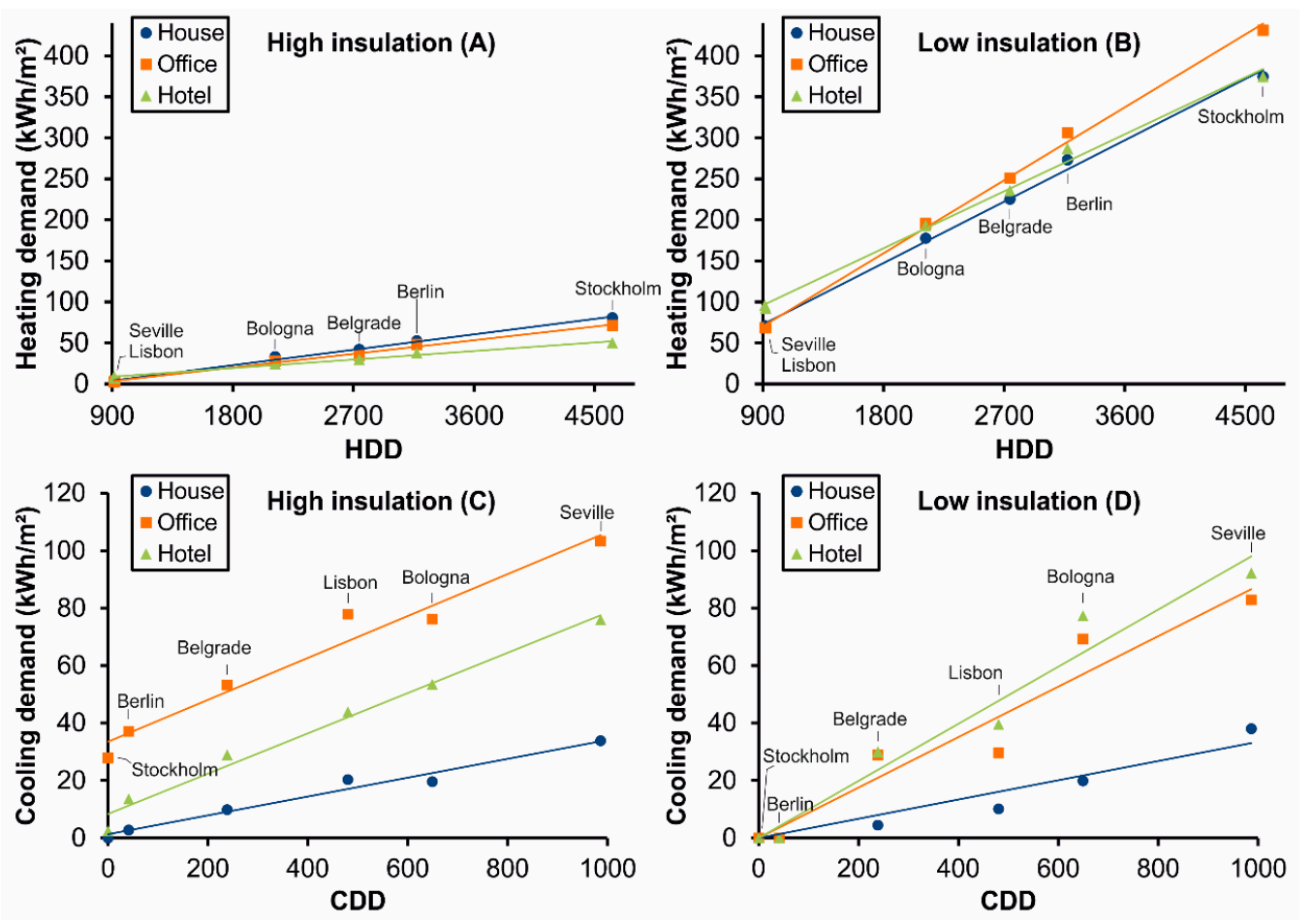

Figure 1. Yearly heating (plots on the top: A,B) and cooling (plots on the bottom $\mathbf{C}, \mathbf{D}$ ) demands, expressed in $\mathrm{kWh} / \mathrm{m}^{2}$, of the 36 benchmark buildings modelled in Rivoire et al. (2018, [21]) from which thermal load data were drawn for BHE sizing. The heating and cooling demands of well-insulated (plots on the left: A,C) and poorly-insulated (plots on the right: B,D) buildings are plotted against the heating (HDD) and cooling (CDD) degree-days (ASHRAE method with reference $18.3{ }^{\circ} \mathrm{C}$, see [25]) calculated for the six hypothesized locations (Seville, Lisbon, Bologna, Belgrade, Berlin, Stockholm). Modified from Rivoire et al. (2018, [21]). 
The dataset of Rivoire et al. (2018, [21]) therefore provides 36 thermal load input combinations with hourly data of heating, cooling, and domestic hot water (DHW) needs. These time series were processed to derive the input data requested by Earth Energy Designer: the monthly demands for heating, cooling, DHW and the monthly peak thermal loads for heating and cooling (DHW demand is considered as constant through the month).

The building-side thermal loads for heating $\left(Q_{h}\right)$, cooling $\left(Q_{c}\right)$ and DHW $\left(Q_{D H W}\right)$ were transformed by Earth Energy Designer into their respective ground-side thermal loads $\left(Q_{h, \text { ground }}, Q_{c, \text { ground }}\right.$, $Q_{D H W, \text { ground }}$ ) depending on the seasonal efficiency (seasonal performance factor, $\mathrm{SPF}$ ) for each function of the heat pump, namely:

$$
\begin{gathered}
Q_{h, \text { ground }}=Q_{h} \cdot \frac{S P F_{h}}{1+S P F_{h}} \\
Q_{c, \text { ground }}=Q_{c} \cdot \frac{1+S P F_{c}}{S P F_{c}} \\
Q_{D H W, \text { ground }}=Q_{D H W} \cdot \frac{S P F_{D H W}}{1+S P F_{D H W}}
\end{gathered}
$$

The SPF values for heating $\left(S P F_{h}\right)$, cooling $\left(S P F_{c}\right)$ and DHW production $\left(S P F_{D H W}\right)$ for Equations (1)-(3) were calculated iteratively as the load-weighted average of the monthly COP and EER values (derived from the monthly fluid temperatures using Equations (5)-(7) reported in Section 2.3.1). The convergence criterion was set to a variation below 0.1 for each of the three SPF values (heating, cooling DHW) from one simulation round to the next one.

\subsection{Sizing and Design of BHE Fields}

BHE fields for each of the 36 input thermal loads were sized using the software Earth Energy Design (EED) [20] based on the g-functions method [26]. EED calculates the minimum BHE length that copes with both fluid temperature thresholds (minimum and maximum) imposed by the user. Thresholds must be set based on the heat pump requirements and, as for heating, on the freezing temperature of the heat carrier fluid. For each of the 36 case studies described in the previous paragraph, the sizing of BHEs was carried out hypothesizing the use of four different heat carrier fluids: propylene glycol at 25\% (PG 25\%) and 33\% (PG33\%) weight concentrations, calcium chloride at 20\% $\left(\mathrm{CaCl}_{2} 20 \%\right.$ ) weight concentration, and pure water. The main physical properties of the heat carrier fluids are reported in Table 1 . The density and the specific heat were assumed as constant, although they slightly vary with temperature, whereas the fluid viscosity was calculated based on the fluid temperature (see Section 2.3.2).

Table 1. Properties of the heat carrier fluids hypothesized: density $\left(\rho_{f}\right)$, specific heat $(c)$,

\begin{tabular}{|c|c|c|c|c|c|c|}
\hline Fluid & Density $\left(\mathrm{kg} / \mathrm{m}^{3}\right)$ & $\begin{array}{l}\text { Specific Heat } \\
\left(\mathrm{J} \cdot \mathrm{kg}^{-1} \cdot \mathrm{K}^{-1}\right)\end{array}$ & $\begin{array}{l}\text { Thermal Conductivity } \\
\left(\mathrm{W} \cdot \mathrm{m}^{-1} \cdot \mathrm{K}^{-1}\right)\end{array}$ & $\begin{array}{l}\text { Freezing } \\
\text { Point }\left({ }^{\circ} \mathrm{C}\right)\end{array}$ & $\begin{array}{l}\text { Minimum BHE Inlet } \\
\text { Temperature }\left({ }^{\circ} \mathrm{C}\right)\end{array}$ & $\begin{array}{l}\text { Maximum BHE Inlet } \\
\text { Temperature }\left({ }^{\circ} \mathrm{C}\right)\end{array}$ \\
\hline Pure water & 999.8 & 4217 & 0.562 & 0 & +3.5 & +31.5 \\
\hline $\mathrm{CaCl}_{2} 20 \%$ & 1195 & 3050 & 0.53 & -18 & -9.5 & +31.5 \\
\hline PG 33\% & 1042 & 3725 & 0.45 & -17 & -9.5 & +31.5 \\
\hline
\end{tabular}
thermal conductivity $\left(\lambda_{f}\right)$, freezing point, and minimum and maximum temperature thresholds set in EED.

A unique value of ground thermal conductivity $\left(2.4 \mathrm{~W} \cdot \mathrm{m}^{-1} \cdot \mathrm{K}^{-1}\right)$ and thermal capacity $\left(2.16 \cdot 10^{6} \mathrm{~J} \cdot \mathrm{m}^{-3} \cdot \mathrm{K}^{-1}\right)$ was set, which is typical of saturated sand [27]. A different ground temperature was instead set for each climatic zone, assuming it equal to the yearly average air temperature: $18^{\circ} \mathrm{C}$ for Seville, $16.8{ }^{\circ} \mathrm{C}$ for Lisbon, $13.4{ }^{\circ} \mathrm{C}$ for Bologna, $11.8{ }^{\circ} \mathrm{C}$ for Belgrade, $9{ }^{\circ} \mathrm{C}$ for Berlin, and $6.6{ }^{\circ} \mathrm{C}$ for Stockholm. The flow rate $\dot{V}_{f}$ was set, for each case, imposing a temperature difference of $3^{\circ} \mathrm{C}$ between the BHE inlet and outlet fluid temperatures. 
The heat transport inside the BHE is modelled with the approach described by Hellstrom [28], i.e., simulating the borehole with two thermal resistances:

- $\quad$ the borehole thermal resistance $R_{b}(\mathrm{mK} / \mathrm{W})$, i.e., the ratio of the difference between the temperatures of the borehole wall and the fluid (average of inlet and outlet values) and the thermal load per unit length $(\mathrm{W} / \mathrm{m})$ of the borehole exchanged with the ground;

- $\quad$ the internal borehole thermal resistance $R_{a}(\mathrm{mK} / \mathrm{W})$, i.e., the ratio of the temperature difference between the inlet and the outlet pipes and the thermal power per unit length $(\mathrm{W} / \mathrm{m})$ exchanged between such pipes (also known as thermal short-circuit).

Ideally, $R_{b}$ should be as low as possible and $R_{a}$ should be as high as possible. These thermal resistances were calculated by EED, using the multipole method of Bennet et al. [29], based on the following input data: borehole diameter $150 \mathrm{~mm}$, filling thermal conductivity of $1.47 \mathrm{~W} \cdot \mathrm{m}^{-1} \cdot \mathrm{K}^{-1}$, a 2U-pipe configuration with pipes made of high density polyethylene (thermal conductivity $0.42 \mathrm{~W} \cdot \mathrm{m}^{-1} \cdot \mathrm{K}^{-1}$ ) with an external diameter of $32 \mathrm{~mm}$ and a thickness of $3 \mathrm{~mm}$ (i.e., the typical value for a pressure resistance of 16 bars). The fluid viscosity and its flow rate, therefore, influence the borehole thermal resistances for each simulated case. A plant lifetime of 25 years was simulated.

With the settings described above, the sizing process was carried out through the "optimization" function of EED, which processes several possible spatial configurations of BHE fields based on spatial constraints imposed by the user (available area, distance, BHE depth range etc.). The BHE depth was constrained between $50 \mathrm{~m}$ and $160 \mathrm{~m}$ (depth limit imposed by the pressure resistance of 16 bars of the chosen pipes). The distance between BHEs ranged between 5 and $20 \mathrm{~m}$ and it is constrained by the available area, which was set to $30 \times 30 \mathrm{~m}$ for the detached house, $50 \times 50 \mathrm{~m}$ for the office building, and $100 \times 100 \mathrm{~m}$ for the hotel. Only in four cases (hotel in the coldest zones Stockholm and Berlin) was the constraint on the available area removed since even the smallest spacing $(5 \mathrm{~m})$ did not allow the drilling of all the needed BHEs filled with water. The least expensive BHE field configuration proposed by EED was finally chosen (see unit costs in Section 2.4).

\subsection{Energy Demand for the Operation of Geothermal Systems}

\subsubsection{Energy Demand of the Heat Pump}

The energy demand of the heat pump $C_{H P}(\mathrm{kWh})$ was calculated on a monthly basis as a function of the building-side monthly demand for heating $Q_{h}(\mathrm{kWh})$, domestic hot water $Q_{D H W}(\mathrm{kWh})$, and cooling $Q_{c}(\mathrm{kWh})$ :

$$
C_{H P}=Q_{h} / C O P_{h}+Q_{D H W} / C O P_{D H W}+Q_{c} / E E R
$$

The values of $C O P_{h}, C O P_{D H W}$ and $E E R$ of the heat pump were also calculated for each month, depending on the "base load temperatures" $T_{f}\left({ }^{\circ} \mathrm{C}\right)$ calculated by EED for the 25th year of operation. The following correlations were calibrated based on the datasheet of a water-water heat pump [30,31]:

$$
\begin{gathered}
C O P_{h}=4.893+0.13 \cdot T_{f} \\
C O P_{D H W}=3.191+0.092 \cdot T_{f} \\
E E R=10.389-0.153 \cdot T_{f}
\end{gathered}
$$

where $T_{f}\left({ }^{\circ} \mathrm{C}\right)$ is the BHE fluid temperature, i.e., the average between inlet and outlet values. The input data for Equations (5)-(7) are based on data for load-side temperatures typical of radiant panels $\left(35^{\circ} \mathrm{C}\right.$ for heating, $15^{\circ} \mathrm{C}$ for cooling) and for a load-side temperature of $50{ }^{\circ} \mathrm{C}$ for DHW production.

\subsubsection{Energy Demand of the Ground-Side Circulation Pump}

The ground-side circulation pump is a key component of a GSHP system and, if operating correctly, its share on the overall energy consumption of the system should not exceed $10 \%$ [3]. The choice of 
the heat carrier fluid influences the circulation pump energy demand through different factors, i.e., fluid viscosity, pipe length, operating temperatures, and, to a lesser extent, fluid density.

According to Casasso and Sethi [18], the energy consumption of the circulation pump $C_{C P}(\mathrm{kWh})$ is described by the following equation:

$$
C_{C P}=\frac{8 \cdot \dot{V}_{f}^{3} \cdot \lambda_{0} \cdot L \cdot \rho_{f}}{\pi^{2} \cdot D^{5} \cdot \eta} \cdot \frac{t_{f u n c}}{1000}
$$

where $\dot{V}_{f}$ is the fluid flow rate of each circuit, $L(\mathrm{~m})$ is the total circuit length (i.e., four times the total BHE length drilled), $\rho_{f}\left(\mathrm{~kg} / \mathrm{m}^{3}\right)$ is the fluid density, $D(\mathrm{~m})$ is the internal pipe diameter, $t_{\text {func }}(\mathrm{h})$ is the operating time of the system, and $\eta$ (non-dimensional) is the ground-side circulation pump efficiency, which was set at $70 \%$.

The parameter $\lambda_{0}$ is the non-dimensional friction loss:

$$
\lambda_{0}=D J / \frac{u_{f}^{2}}{2 g}
$$

where $J$ is the hydraulic gradient (i.e., the friction loss per unit pipe length), $g=9.81 \mathrm{~m} / \mathrm{s}^{2}$ is the gravity acceleration, and $u_{f}=\dot{V}_{f} /\left(\frac{\pi D^{2}}{4}\right)(\mathrm{m} / \mathrm{s})$ is the fluid velocity.

The non-dimensional friction loss is expressed with the Hagen-Poiseuille formula for laminar flow $(\operatorname{Re}<2300)$ :

$$
\lambda_{0}=64 / R e
$$

and with the Prandtl formula for hydraulically smooth pipes (see [18]) for $R e>2300$ :

$$
\lambda_{0}=\frac{0.25}{\left[\left(\log _{10}\left(\frac{5.7}{R^{0.9}}\right)\right]^{2}\right.}
$$

where $R e=\rho_{f} u_{f} D / \mu_{f}$ is the Reynolds number and $\mu_{f}(\mathrm{~Pa} \cdot \mathrm{s})$ is the fluid dynamic viscosity.

The dynamic viscosity $\mu_{f}$ is a key parameter to calculate the value of the energy consumption of the ground-side circulation pump and it depends on the fluid temperature. For this reason, the following exponential correlation was used to fit available viscosity values (see [19]):

$$
\mu_{f}=A \cdot \exp \left(B \cdot T_{f}\right)
$$

where $T_{f}\left({ }^{\circ} \mathrm{C}\right)$ is the fluid temperature and $A(\mathrm{~Pa} \cdot \mathrm{s})$ and $B\left({ }^{\circ} \mathrm{C}^{-1}\right)$ are the fitting coefficients $(A$ is the viscosity value at $0{ }^{\circ} \mathrm{C}$ ) reported in Table 2 for each fluid considered.

Table 2. Coefficients of the fluid viscosity correlation with temperature (Equation (12)).

\begin{tabular}{ccc}
\hline Fluid & A (Pa.s) & B $\left({ }^{\circ} \mathbf{C}^{-\mathbf{1}}\right)$ \\
\hline Pure water & $1.81 \times 10^{-3}$ & -0.024 \\
PG 25\% & $5.49 \times 10^{-3}$ & -0.0322 \\
PG 33\% & $8.74 \times 10^{-3}$ & -0.0386 \\
$\mathrm{CaCl}_{2} 20 \%$ & $3.34 \times 10^{-3}$ & -0.03 \\
\hline
\end{tabular}

\subsection{Economic Evaluation}

The choice of the fluid has an economic impact on different components of the installation and operational costs of a GSHP. The installation costs are influenced by the chosen fluid as this determines the required $\mathrm{BHE}$ length and, to a lesser extent, by the cost of the antifreeze additive itself. Indeed, 
using a fluid with a higher freezing temperature requires a greater length to be installed to cope with the minimum fluid temperature requirements.

The BHE installation cost was assumed considering three components:

- A cost of $1000 €$ was fixed for each borehole, independently from their depth, to consider the cost of the double U-pipe;

- A unit cost of vertical drilling and grouting of $50 € / \mathrm{m}$;

- An excavation cost of $30 € / \mathrm{m}$ for collector trenches (their length is computed by EED based on the chosen configuration).

With these values of BHE installation unit costs, EED performed the optimization to find the least expensive configuration coping with fluid temperature requirements (Section 2.1).

The unit costs of antifreeze additives were set to $5 € / \mathrm{kg}$ for propylene glycol and $0.8 € / \mathrm{kg}$ for calcium chloride.

The operational costs of the heat pump and of the ground-side circulation pump depend on the fluid. The impact was evaluated considering an energy cost of $0.21 € / \mathrm{kWh}$ based on recent Eurostat estimates [32]. The energy consumption of the heat pump is influenced by the chosen heat carrier fluid, which has different operating temperatures according to the different BHE lengths installed. The longer the BHEs installed, the higher the fluid temperatures (and, hence, the COP) in the heating season and the lower the fluid temperature in the cooling season (and, hence, the higher the EER); as a consequence, longer BHEs result in a lower energy demand by the heat pump. On the other hand, the energy demand of the ground-side circulation pump $\left(C_{C P}\right)$ increases with the length of BHE pipes through which the fluid circulates and depends on the viscosity of the fluid, which is function of the chosen fluid and of the operating temperature (see Section 2.3.2).

\subsection{Carbon Footprint Evaluation}

The carbon footprint is a measure of GHG emissions that are directly and indirectly caused by an activity or are accumulated over the life stages of a product. The equivalent $\mathrm{CO}_{2}$ emissions of each simulated plant were estimated considering both the installation and the operating lifetime emissions. $\mathrm{CO}_{2}$ equivalent $\left(\mathrm{CO}_{2}\right.$ eq. $)$ is the quantity of carbon dioxide producing the same global warming impact of a mix of different GHGs. It is used to compare and sum the contributions of different greenhouse gases such as $\mathrm{CH}_{4}, \mathrm{~N}_{2} \mathrm{O}, \mathrm{SF}_{6}$, heat pump refrigerants, etc. The $\mathrm{CO}_{2}$ eq. of a certain $\mathrm{GHG}$ is calculated by multiplying its mass for a coefficient called Global Warming Potential (GWP), which expresses the ability of the considered GHG to absorb heat during a certain period (generally, 100 years) [33].

The carbon footprint of the BHE installation was assessed using the OpenLCA software [34], obtaining a value of $25.61 \mathrm{~kg} \mathrm{CO} 2 \mathrm{eq} . / \mathrm{m}$ of BHE. Heat carrier fluids were assessed separately using the reference values of OpenLCA, i.e., $4.67 \mathrm{~kg} \mathrm{CO}$ eq. per $\mathrm{kg}$ of propylene glycol and $1.02 \mathrm{~kg} \mathrm{CO}_{2}$ eq. per $\mathrm{kg}$ of calcium chloride, whereas the carbon footprint of water was neglected.

The carbon footprint during the operational lifetime was assessed considering the electricity consumption of the heat pump and the ground-side circulation pump. The emission factor of electricity proposed by the Italian national environmental protection agency (ISPRA, 2017 [35]), equal to $0.304 \mathrm{kgCO}_{2}$ eq./ $/ \mathrm{kWh}$, was used.

\section{Results and Discussion}

This section presents the results of the 144 simulations carried out, highlighting the energetic, economic, and environmental impacts of choosing among four different heat carrier fluids (pure water, PG 25\%, PG 33\% and $\mathrm{CaCl}_{2} 20 \%$ ). Section 3.1 presents the relative variation of the $\mathrm{BHE}$ length to be installed with different fluids. Section 3.2 presents the evaluation of normalized life cycle costs for the installation and the 25-year plant operation, whereas Section 3.3 presents the carbon footprint assessment on the same period. 


\subsection{Sizing of BHE Fields}

The choice of the heat carrier fluid has a strong impact on the length of the BHE to be installed, since it determines the minimum temperature threshold to be set (see Table 1 and Section 2.2). Pure water has the highest minimum threshold temperature $\left(+3.5^{\circ} \mathrm{C}\right)$ and, hence, BHEs using this heat carrier fluid are expected to be longer than those operating with anti-freeze additives, i.e., PG $25 \%$ $\left(-4.5^{\circ} \mathrm{C}\right), \mathrm{PG} 33 \%\left(-9.5^{\circ} \mathrm{C}\right)$, and $\mathrm{CaCl}_{2} 20 \%\left(-9.5^{\circ} \mathrm{C}\right)$. Therefore, a comparison was made between the resulting lengths with pure water and $\mathrm{CaCl}_{2} 20 \%$ (Figure 2), and between water and PG25\% (Figure 3). The plots show 36 comparisons each, i.e., the three building types (hotel, office, and residential), each with high or low insulation, for each of the six climate zones represented by as many cities (Seville, Bologna, Lisbon, Belgrade, Berlin, and Stockholm).

The detailed results of the sizing procedure, i.e., the number and depth of BHEs for each of the 144 configurations, are reported in the Supplementary Materials (Table S2).

The plots reported below show that the needed BHE length dramatically increases, when choosing water instead of $\mathrm{CaCl}_{2} 20 \%$ as a heat carrier fluid (Figure 2), in very cold climates, such as Berlin (from $+248 \%$ to $+580 \%$ ) and Stockholm (from $+431 \%$ to $+1769 \%$ ). Such a large difference is due to two factors, namely (1) an unbalanced heating-dominated (or heating-only) thermal load, with a consequent negative thermal balance of the ground, and (2) a low undisturbed ground temperature and, hence, a more limited margin with respect to the minimum threshold temperature. Differences of BHE length increment between different building types are due to two factors, namely (1) the different heating/cooling load ratio (as shown in Figure 1, office buildings and hotels have relatively higher cooling needs compared to residential buildings), and (2) the BHE field size effect on the reciprocal thermal interference between neighboring BHEs (i.e., as the number of BHEs increases, each borehole is more impacted by the thermal alteration induced by neighboring boreholes).

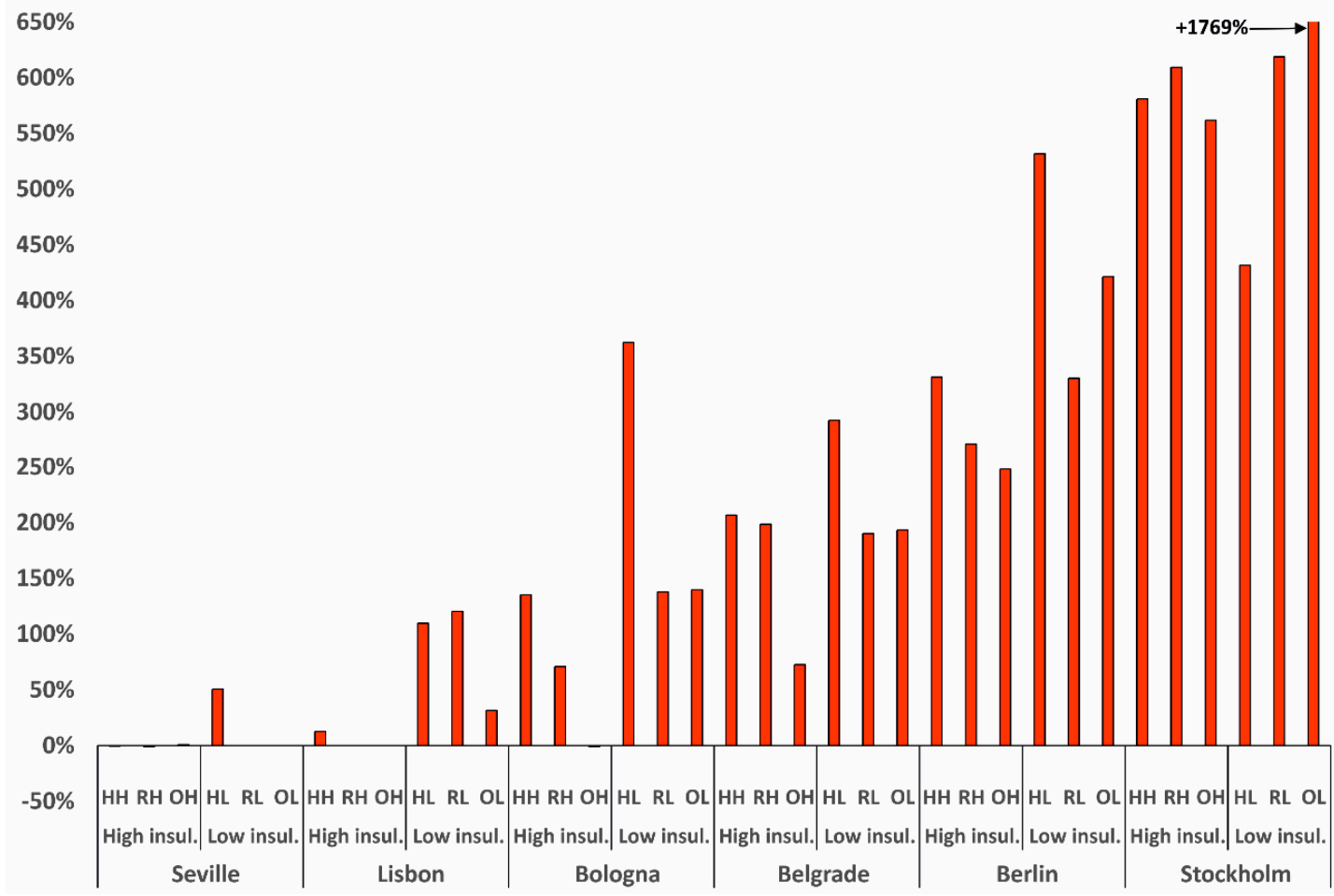

Figure 2. Relative increase of the total length of BHEs to be installed due to the use of pure water instead of $\mathrm{CaCl}_{2} 20 \%$, for each climate zone (Seville, Bologna, Lisbon, Belgrade, Berlin, Stockholm) and each building type (HH, RH, OH: Hotel, residential, and office with high insulation; HL, RL, OL: Hotel, residential, and office with low insulation). 


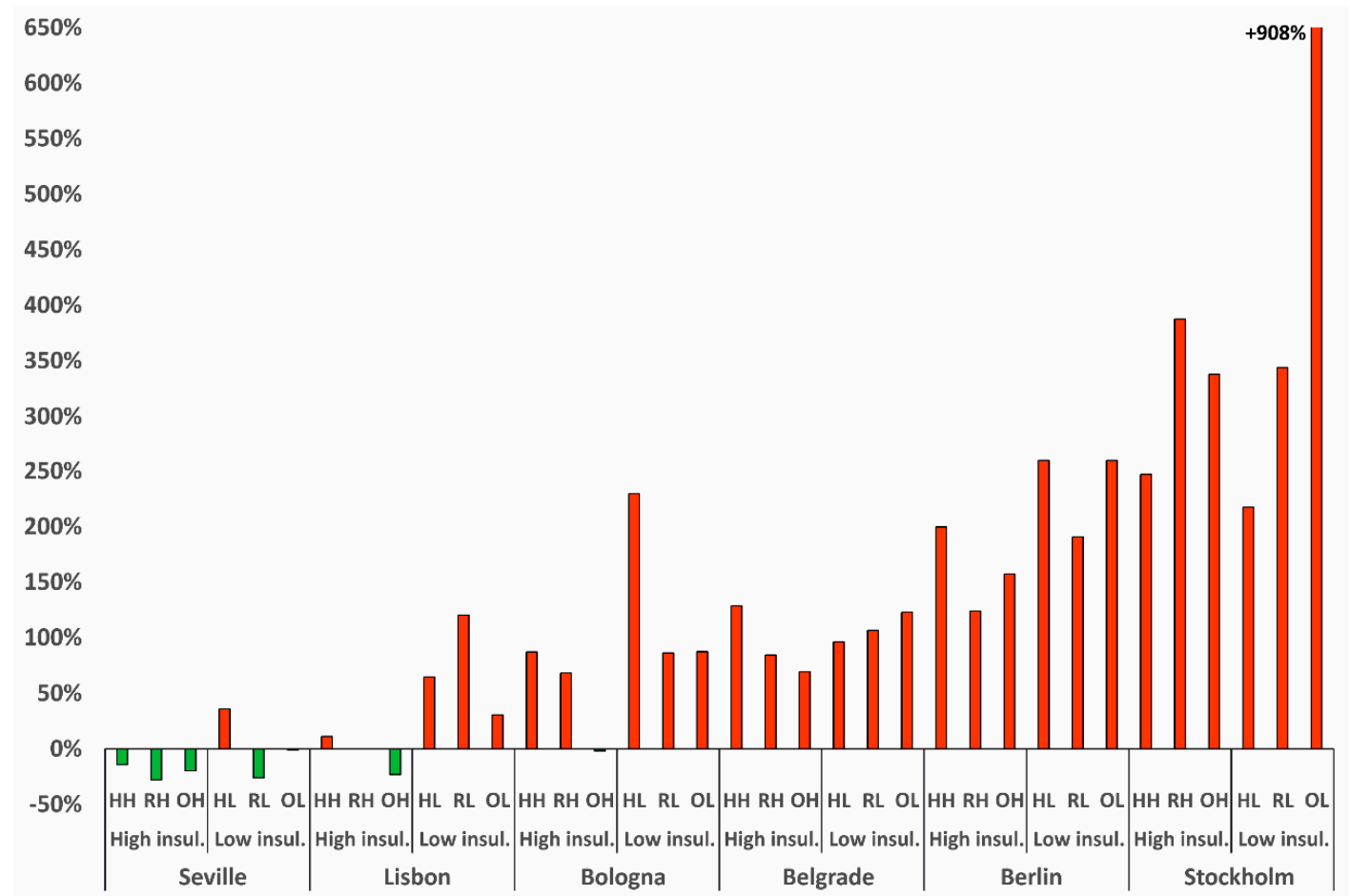

Figure 3. Relative increase of the total length of BHEs to be installed due to the use of pure water instead of propylene glycol 25\%, for each climate zone (Seville, Bologna, Lisbon, Belgrade, Berlin, Stockholm) and each building type ( $\mathrm{HH}, \mathrm{RH}, \mathrm{OH}$ : Hotel, residential, and office with high insulation; HL, RL, OL: Hotel, residential and, office with low insulation).

Similar, but smaller increments of the needed BHE lengths are observed comparing water and PG25\% (Figure 3). The increase of the needed BHE length is lower, or even null, in warm climates such as Seville and Lisbon. In intermediate climate zones, the increase of the needed BHE length is in the order of $100-200 \%$ using water instead of PG $25 \%$. The results confirm that using pure water as a heat carrier fluid is almost unfeasible in cold climates (Stockholm and Berlin) and implies a significant increase of installation costs in temperate climates (Belgrade and Bologna). Only in warm climates (represented by Seville and Lisbon), with a cooling-dominated thermal load and a high undisturbed ground temperature, did the use of pure water have no impact on the BHE length and, hence, on installation costs. In these climate zones, using pure water instead of PG $25 \%$ can even lead to an appraisable reduction of the BHE length (Figure 3) thanks to the lower viscosity of water, which slightly reduces the borehole thermal resistance $R_{b}$.

\subsection{Economic Evaluation}

As explained in Section 2.4, the overall costs evaluated on a 25-year plant lifetime comprise the drilling and installation of BHEs, the costs for the heat carrier fluid (installation and one replacement every five years), the electricity for the heat pump and for the ground-side circulation pump. There are other cost components- the installation of the heat pump, the possible replacement or installation of heating and cooling terminals, and the civil works needed-which were not considered in our analysis since their value is assumed to be the same regardless of the heat carrier fluid.

A comparison of the overall costs of GSHP systems, depending on the chosen heat carrier fluid, is shown in Figure 4 (residential building), Figure 5 (hotel building) and Figure 6 (office building). For each of the 36 case studies simulated, PG25\% was taken for reference and the relative cost variations using other fluids (pure water, $\mathrm{CaCl} 220 \%$, and $\mathrm{PG} 33 \%$ ) are shown. 
The purpose of this economic analysis was to assess whether the use of water as a heat carrier fluid for BHEs-which implies a higher installation cost-can be compensated by lower operational costs due to the following savings:

- lower heat pump energy demand, thanks to higher fluid operating temperatures in heating mode (coping with a higher minimum threshold temperature) and, as an effect of longer BHEs, lower fluid operating temperatures in cooling mode;

- lower ground-side circulation pump energy demand, due to the lower viscosity of the fluid. However, it should also be considered that BHEs using pure water have longer pipe loops (due to longer BHEs), so it is not granted that using water will always reduce the consumption of the circulation pump;

- the cost of the antifreeze additive and of its periodic replacement (once every five years) is avoided.

The values of energy demand of the heat pump and the ground-side circulation pump at the 25th year of operation are reported in Table S3 in the Supplementary Materials, whereas the values of each cost component (BHE installation, fluid replacement, and the operational costs of the heat pump and the circulation pump over 25 years) are reported in Table S4.

The results shown in Figures 4-6 reveal that using pure water as a heat carrier fluid is economically convenient only for cooling-dominated buildings, i.e., for buildings in the warmest climate zones (Seville and Lisbon) and, to a lesser extent, for well-insulated residential and office buildings in Bologna. For all other climate zones, using water instead of PG25\% leads to an increase of the lifetime costs which, however, is moderate (generally below $20 \%$ ) in the temperate climates of Bologna and Belgrade. On the other hand, using water instead of PG25\% leads to noticeable increase of lifetime costs (up to $+285 \%$ ) in the coldest climate zones Berlin and Stockholm. Most of such a large extra cost is due to the BHE installation (see Table S4 in the Supplementary Materials).

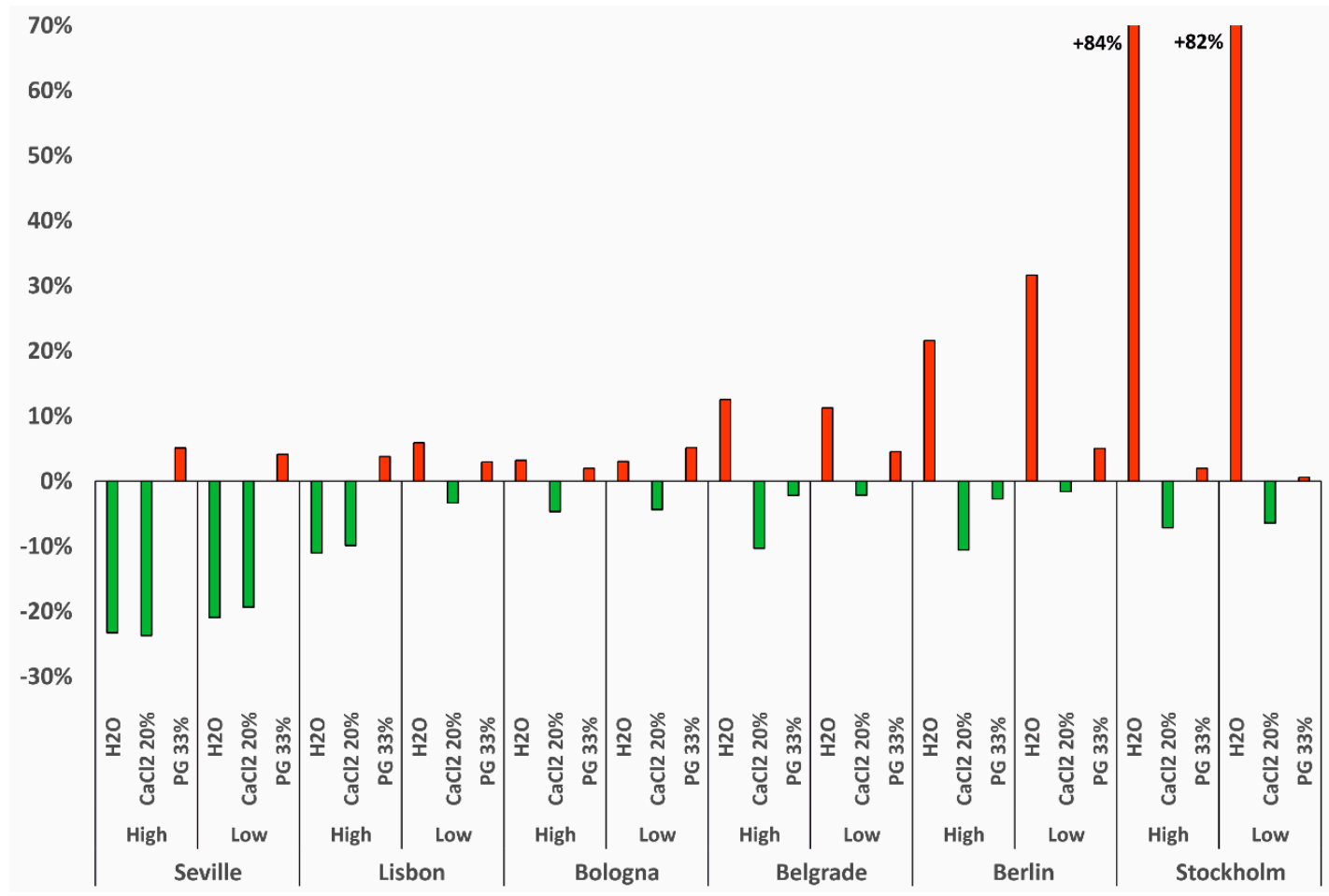

Figure 4. Life cycle cost variation due to the choice of different fluids (water, $\mathrm{CaCl}_{2} 20 \%, \mathrm{PG} 33 \%$ ), compared to the standard PG25\%, for the benchmark residential building. 


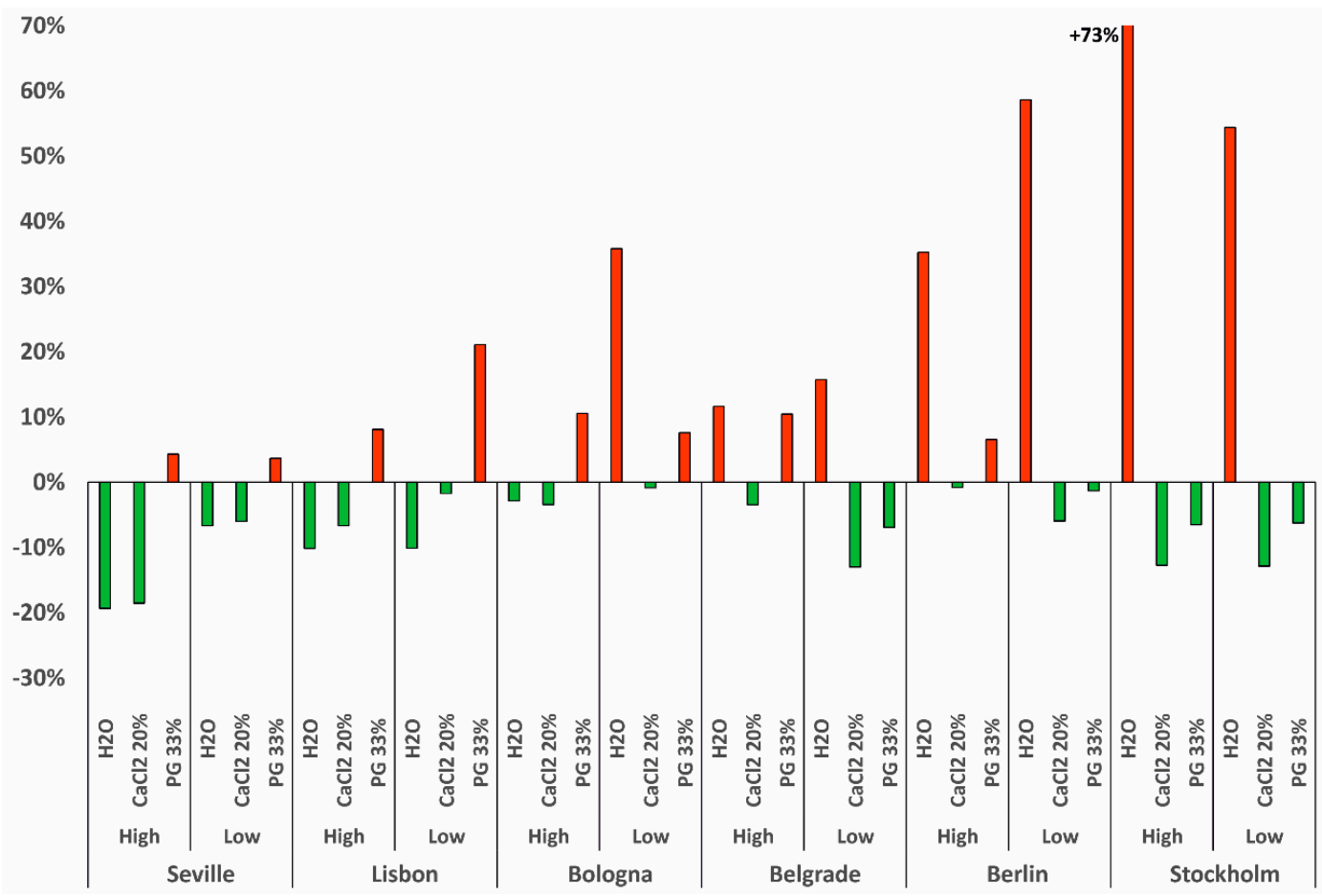

Figure 5. Life cycle cost variation due to the choice of different fluids (water, $\mathrm{CaCl}_{2} 20 \%, \mathrm{PG} 33 \%$ ), compared to the standard PG25\%, for the benchmark hotel building.

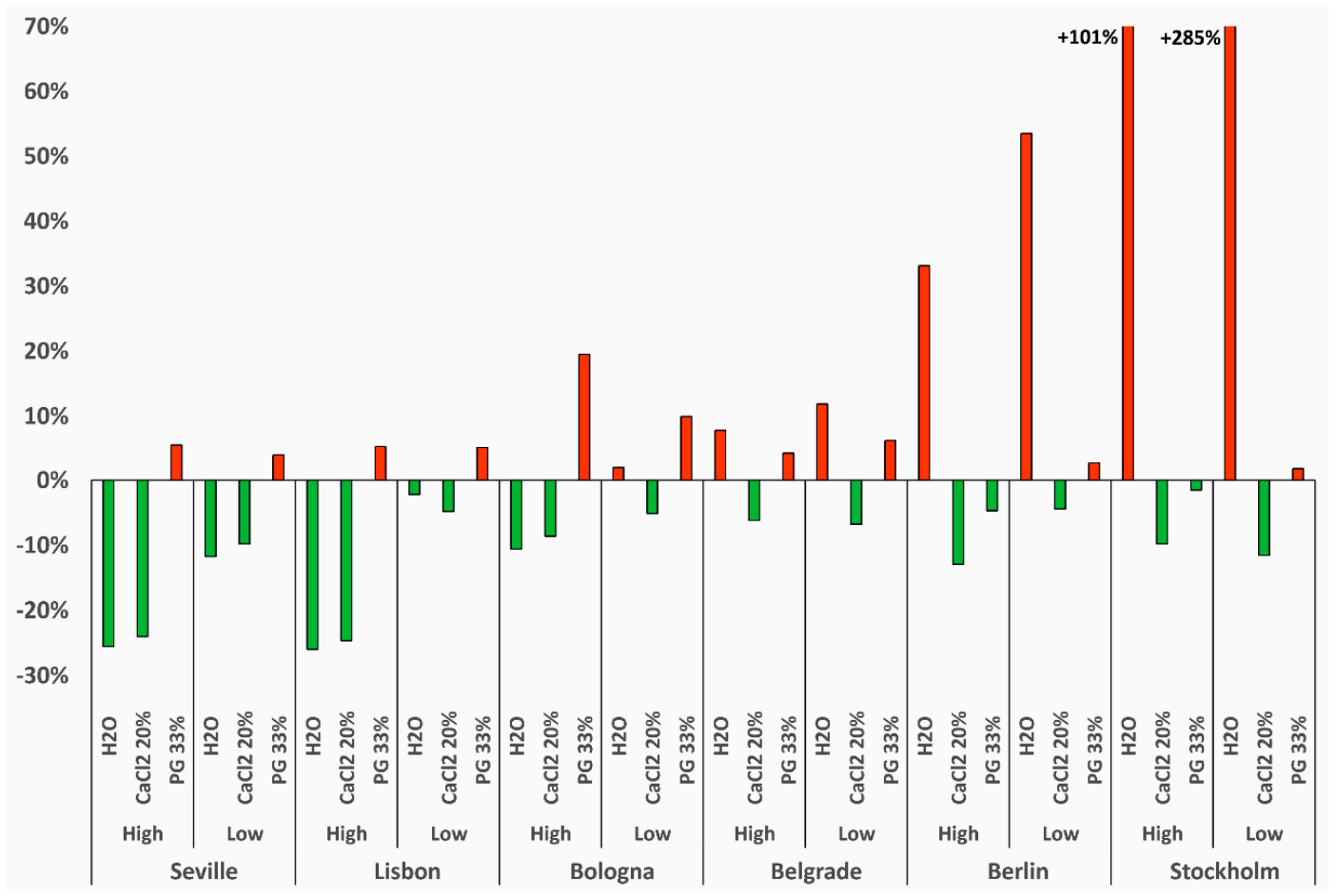

Figure 6. Life cycle cost variation due to the choice of different fluids (water, $\mathrm{CaCl}_{2} 20 \%, \mathrm{PG} 33 \%$ ), compared to the standard PG25\%, for the benchmark office building.

Increasing the concentration of propylene glycol from $25 \%$ to $33 \%$ leads to some savings only in heating-dominated buildings such as the ones located in Stockholm and, in a few cases, in Berlin and Belgrade. Among different antifreeze fluids, PG33\% appears to be the most expensive solution due to an increase of both the antifreeze cost and of the circulation pump life cycle cost. On the other hand, calcium chloride is more economically convenient than PG25\% in almost all simulated cases. 
The breakdown of the overall costs among different components shown in Figures 4-6 is summarized in Table 3 for different building types and in Table 4 for different heat carrier fluids. The energy cost of the heat pump has generally the largest share, followed by the BHE installation costs. BHE installation costs have the highest share for two kinds of simulated cases, namely, (1) warm areas (Seville and Lisbon) and especially in office buildings, due to a lower number of operating hours, and (2) BHEs using water, due to the greater length of BHEs to be installed. As expected, the lowest fraction for the operation of the ground-side circulation pump is achieved using water as a heat carrier fluid, followed by PG25\%. The replacement of the heat carrier fluid is null for water, has a negligible impact for $\mathrm{CaCl}_{2}$, whereas it has a similar impact for PG at $25 \%$ and $33 \%$ : indeed, using PG33\% generally results in a shorter BHE length installed, which partially compensates the largest share of glycol used.

Table 3. Shares of the BHE installation, heat pump and ground-side circulation pump energy demand, and heat carrier fluid replacement on the lifetime cost (evaluated on 25 years of operation) of the simulated GSHP systems, for different building types (residential, hotel, office).

\begin{tabular}{cccccc}
\hline \multirow{2}{*}{ Building Type } & & \multicolumn{4}{c}{ Share of Overall Lifetime Cost } \\
\cline { 3 - 6 } & & $\begin{array}{c}\text { BHE } \\
\text { Installation }\end{array}$ & $\begin{array}{c}\text { Heat Pump } \\
\text { Operation }\end{array}$ & $\begin{array}{c}\text { Circulation Pump } \\
\text { Operation }\end{array}$ & $\begin{array}{c}\text { Heat } \\
\text { Carrier Fluid }\end{array}$ \\
\hline \multirow{2}{*}{ Residential (RH and RL) } & Range & $16.9-69.5 \%$ & $29.7-76.4 \%$ & $0.1-12.4 \%$ & $0-15.4 \%$ \\
& Average & $34.4 \%$ & $58.1 \%$ & $3.7 \%$ & $3.7 \%$ \\
\hline \multirow{2}{*}{ Hotel (HH and HL) } & Range & $13.6-71.6 \%$ & $28.1-76.3 \%$ & $0.1-19.2 \%$ & $0-15 \%$ \\
& Average & $31.6 \%$ & $58.6 \%$ & $6.5 \%$ & $3.3 \%$ \\
\hline \multirow{2}{*}{ Office (OH and OL) } & Range & $16.4-87 \%$ & $12.8-70.3 \%$ & $0.2-18.4 \%$ & $0-16.7 \%$ \\
& Average & $40.6 \%$ & $48.7 \%$ & $6.2 \%$ & $4.5 \%$ \\
\hline
\end{tabular}

Table 4. Shares of the BHE installation, heat pump and ground-side circulation pump energy demand, and heat carrier fluid replacement on the lifetime cost (evaluated on 25 years of operation) of the simulated GSHP systems, for different fluids $\left(\mathrm{CaCl}_{2} 20 \%\right.$, PG25\%, PG33\%, water).

\begin{tabular}{cccccc}
\hline \multirow{2}{*}{ Heat Carrier Fluid } & \multicolumn{4}{c}{ Share of Overall Lifetime Cost } \\
\cline { 3 - 6 } & & $\begin{array}{c}\text { BHE } \\
\text { Installation }\end{array}$ & $\begin{array}{c}\text { Heat Pump } \\
\text { Operation }\end{array}$ & $\begin{array}{c}\text { Circulation Pump } \\
\text { Operation }\end{array}$ & $\begin{array}{c}\text { Heat } \\
\text { Carrier Fluid }\end{array}$ \\
\hline \multirow{2}{*}{$\mathrm{CaCl}_{2} 20 \%$} & Range & $15.3-61.7 \%$ & $34.7-76.4 \%$ & $0.8-15.9 \%$ & $0.1-0.4 \%$ \\
& Average & $28.6 \%$ & $64 \%$ & $7.2 \%$ & $0.2 \%$ \\
\hline \multirow{2}{*}{$\mathrm{PG} 25 \%$} & Range & $18-60 \%$ & $26-70 \%$ & $0.7-16.1 \%$ & $4-13.2 \%$ \\
& Average & $32.7 \%$ & $55.2 \%$ & $4.8 \%$ & $7.3 \%$ \\
\hline \multirow{2}{*}{$\mathrm{PG} 33 \%$} & Range & $13.6-57.6 \%$ & $24.6-68.7 \%$ & $0.7-19.2 \%$ & $4-16.7 \%$ \\
& Average & $27.2 \%$ & $56.7 \%$ & $8.1 \%$ & $8 \%$ \\
\hline \multirow{2}{*}{ Water } & Range & $26.9-7 \%$ & $12.8-66.9 \%$ & $0.1-9.5 \%$ & $0 \%$ \\
& Average & $53.6 \%$ & $44.6 \%$ & $1.7 \%$ & \multirow{2}{*}{0} \\
\hline
\end{tabular}

\subsection{Carbon Footprint Evaluation}

The choice of the heat carrier fluid impacts the total carbon footprint in different ways. Choosing pure water generally requires a greater BHE length to be installed (see Section 2.2), thus increasing the carbon footprint related to the installation. On the other hand, the higher COP and EER of the heat pump and the lower fluid viscosity reduce the GHG emissions related to the operation of the heat pump and the ground-side circulation pump, respectively. The plots reported below show the variation of life cycle GHG emissions per building category-residential (Figure 7), hotel (Figure 8), and office (Figure 9) -due to the use of various fluids (water, $\mathrm{CaCl}_{2} 20 \%, \mathrm{PG} \mathrm{33 \%}$ ) in comparison to the standard solution with $\mathrm{PG} 25 \%$. These plots reveal that using water as a heat carrier fluid leads to a reduction of GHG emissions, with a few exceptions for heating-dominated buildings in the coldest climate zones (Stockholm and Berlin). Similarly to the life cycle costs, benefits are higher in warm climates (Seville, Lisbon). On the other hand, using water becomes the most carbon-intensive solution 
in the coldest climate zone (Stockholm) due to the noticeable increase of the BHE length to be installed (see Section 3.1). As for GHG emissions, PG 33\% is never beneficial compared to PG $25 \%$. By contrast, $\mathrm{CaCl}_{2} 20 \%$ almost always provides a reduction of GHG emissions compared to PG25\% and it becomes the least carbon intensive solution in the coldest climate zone (Stockholm).

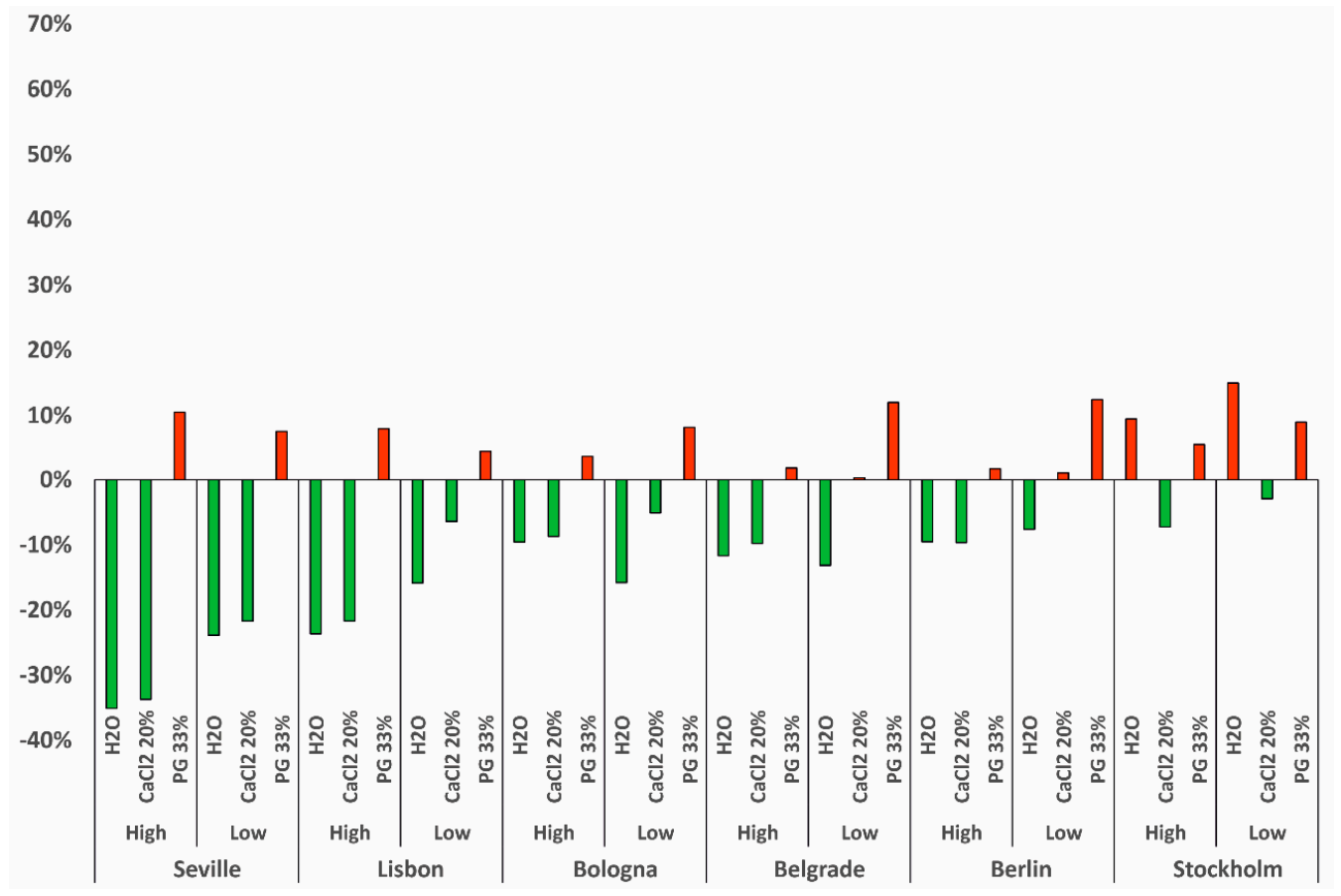

Figure 7. Variation of the life cycle carbon footprint due to the choice of different fluids (water, $\mathrm{CaCl}_{2} 20 \%$, PG33\%), compared to the standard PG25\%, for the benchmark residential building.

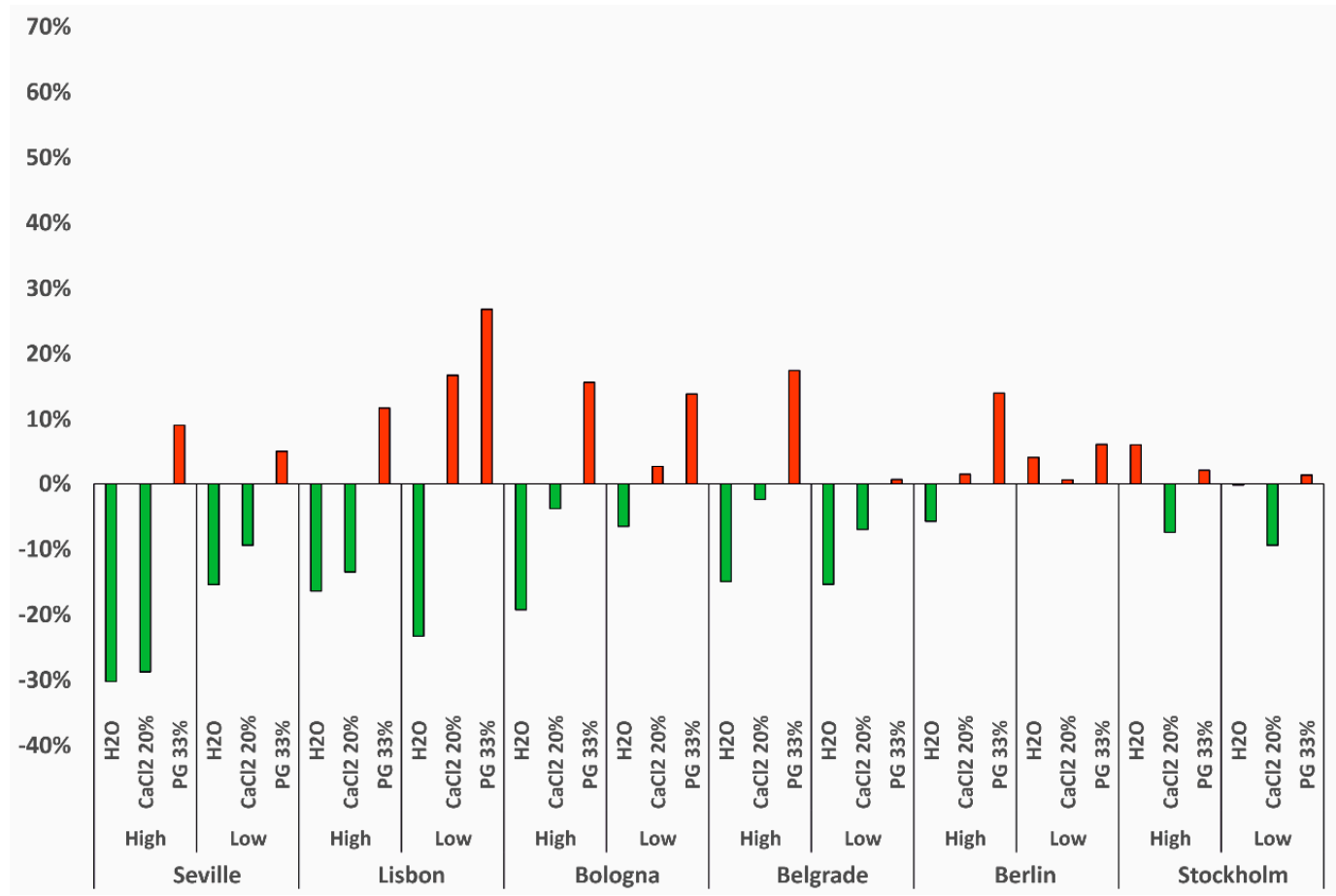

Figure 8. Variation of the life cycle carbon footprint due to the choice of different fluids (water, $\mathrm{CaCl}_{2} 20 \%$, PG33\%), compared to the standard PG25\%, for the benchmark hotel building. 


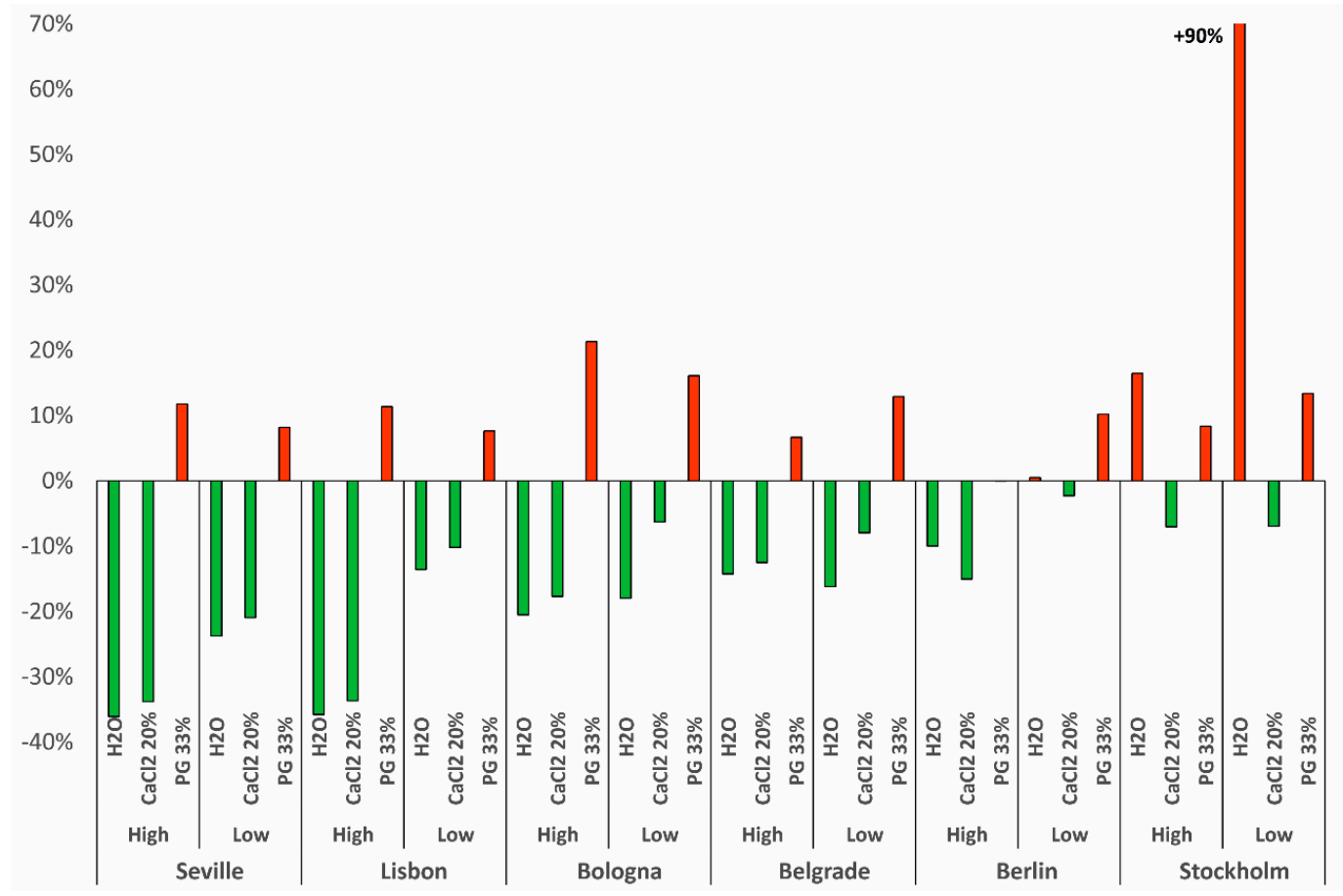

Figure 9. Variation of the life cycle carbon footprint due to the choice of different fluids (water, $\mathrm{CaCl}_{2} 20 \%$, PG33\%), compared to the standard PG25\%, for the benchmark office building.

Tables 5 and 6 summarize the resulting breakdown of GHG emissions related to BHE installation, heat pump operation, ground-side circulation pump operation, and heat carrier fluid replacement depending on the building type and on the heat carrier fluid used, respectively. As expected, the heat pump operation prevails on the other items. The circulation pump operation has a larger impact on BHEs using PG33\% compared to the other fluids (Table 6). The BHE installation has a larger impact in warm climates (Seville, Lisbon), due to the lower number of plant operating hours (and hence the relatively lower impact of heat pump and circulation pump operation), and for BHEs using water in cold climates (Berlin, Stockholm), since avoiding the use of antifreeze in cold climates results in a noticeable increase of the installed BHE length.

Table 5. Shares of the BHE installation, heat pump and ground-side circulation pump energy demand, and heat carrier fluid replacement on the lifetime GHG emissions (evaluated on 25 years of operation) of the simulated GSHP systems, for different building types (residential, hotel, office).

\begin{tabular}{cccccc}
\hline \multirow{2}{*}{ Building Type } & & \multicolumn{4}{c}{ Share of Overall GHG Emissions } \\
\cline { 3 - 6 } & & $\begin{array}{c}\text { BHE } \\
\text { Installation }\end{array}$ & $\begin{array}{c}\text { Heat Pump } \\
\text { Operation }\end{array}$ & $\begin{array}{c}\text { Circulation Pump } \\
\text { Operation }\end{array}$ & $\begin{array}{c}\text { Heat } \\
\text { Carrier Fluid }\end{array}$ \\
\hline \multirow{2}{*}{ Residential (RH and RL) } & Range & $6.2-40.6 \%$ & $42.7-90.3 \%$ & $0.2-13.5 \%$ & $0-17.2 \%$ \\
& Average & $17.9 \%$ & $73.9 \%$ & $4.4 \%$ & $3.7 \%$ \\
\hline \multirow{2}{*}{ Hotel (HH and HL) } & Range & $5-42.6 \%$ & $45.6-88.3 \%$ & $0.3-20.7 \%$ & $0-16.4 \%$ \\
& Average & $16.5 \%$ & $72.7 \%$ & $7.5 \%$ & $3.2 \%$ \\
\hline \multirow{2}{*}{ Office (OH and OL) } & Range & $7.3-67.4 \%$ & $32.1-82.1 \%$ & $0.3-20 \%$ & $0-19.4 \%$ \\
& Average & $22.9 \%$ & $64.7 \%$ & $7.7 \%$ & $4.7 \%$ \\
\hline
\end{tabular}


Table 6. Shares of the BHE installation, heat pump and ground-side circulation pump energy demand, and heat carrier fluid replacement on the lifetime GHG emissions (evaluated on 25 years of operation) of the simulated GSHP systems, for different fluids $\left(\mathrm{CaCl}_{2} 20 \%, \mathrm{PG} 25 \%\right.$, PG33\%, water).

\begin{tabular}{cccccc}
\hline \multirow{2}{*}{ Heat Carrier Fluid } & \multicolumn{4}{c}{ Share of Overall Lifetime Cost } \\
\cline { 3 - 6 } & & $\begin{array}{c}\text { BHE } \\
\text { Installation }\end{array}$ & $\begin{array}{c}\text { Heat Pump } \\
\text { Operation }\end{array}$ & $\begin{array}{c}\text { Circulation Pump } \\
\text { Operation }\end{array}$ & $\begin{array}{c}\text { Heat } \\
\text { Carrier Fluid }\end{array}$ \\
\hline \multirow{2}{*}{$\mathrm{CaCl}_{2} 20 \%$} & Range & $5-32.9 \%$ & $60.6-90.3 \%$ & $1.4-17.9 \%$ & $0.1-0.7 \%$ \\
& Average & $11.6 \%$ & $79.4 \%$ & $8.8 \%$ & $0.2 \%$ \\
\hline \multirow{2}{*}{ PG 25\% } & Range & $9.5-42.9 \%$ & $39.5-80.7 \%$ & $1-18 \%$ & $3.6-16.2 \%$ \\
& Average & $19.7 \%$ & $67.1 \%$ & $5.8 \%$ & $7.4 \%$ \\
\hline \multirow{2}{*}{ PG 33\% } & Range & $7.9-43.7 \%$ & $35.3-78.2 \%$ & $1-20.7 \%$ & $3.5-19.4 \%$ \\
& Average & $17.7 \%$ & $65.4 \%$ & $9.1 \%$ & $7.8 \%$ \\
\hline \multirow{2}{*}{ Water } & Range & $10-67.4 \%$ & $32.1-82.9 \%$ & $0.2-12.9 \%$ & $0 \%$ \\
& Average & $27.3 \%$ & $70.1 \%$ & $2.6 \%$ & \multirow{2}{*}{0} \\
\hline
\end{tabular}

\section{Conclusions}

Ground source heat pumps are known as one of the least carbon intensive techniques for the heating and cooling of buildings, however, research is still trying to exploit all the margins of carbon footprint reduction. Among them, the choice of the proper heat carrier fluid has noticeable environmental and economic impacts. This holds true, in particular, for the underground heat extraction for heating and DHW production, since the fluid temperatures in this case are expected to fall below $0{ }^{\circ} \mathrm{C}$. Two approaches can be adopted: sizing BHEs in order to keep the fluid temperature well above $0{ }^{\circ} \mathrm{C}$, thus allowing the use of pure water, or to employ antifreeze additives to lower the minimum temperature threshold. Concerns on groundwater pollution led to the issuing of some local regulations which require pure water to be used, and this paper analyzed the techno-economic feasibility and possible environmental benefits of such choice.

In this paper, an analysis was conducted based on 36 simulated thermal loads, representative of six buildings (a hotel, a detached house, and an office building with low or high insulation) in six climate zones (represented by these cities: Seville, Lisbon, Bologna, Belgrade, Berlin, and Stockholm). The same geological conditions were assigned for all the 144 cases simulated (saturated sand with a conductivity of $2.4 \mathrm{~W} \cdot \mathrm{m}^{-1} \cdot \mathrm{K}^{-1}$ ) since the evaluation of specific installation sites was beyond the purpose of this study. On the other hand, site-specific undisturbed ground temperature values were assigned because this parameter mostly depends on the climate. BHE fields were sized to cover the thermal loads using the EED software and setting different fluid temperature constraints for pure water (minimum $+3.5^{\circ} \mathrm{C}$ inlet temperature), PG $25 \%$ (threshold $-4.5^{\circ} \mathrm{C}$ ), $\mathrm{CaCl}_{2}$ at $20 \%$ and PG $33 \%$ (threshold $-9.5^{\circ} \mathrm{C}$ ). The fluid temperatures resulting from the EED simulations were used to estimate the efficiency of the heat pump (COP for heating and DHW production, EER for cooling) and the viscosity of the heat carrier fluid, hence the electricity demand of the heat pump and of the ground-side circulation pump, respectively. The lifetime costs and GHG emissions were estimated considering the borehole drilling and installation, the periodic replacement of the fluid and the electricity demand for the operation of the system (heat pump and ground-side circulation pump). The results highlighted that pure water can successfully be employed for cooling-dominated buildings (i.e., in Seville, Lisbon and in well-insulated buildings in Bologna), for which the ground heat extraction is not intense. On he other hand, filling BHE pipes with pure water is hardly feasible in cold climates (e.g., cities like Berlin and Stockholm) since it leads to a significant oversizing of BHE fields that hampers the economic sustainability of a GSHP system. The lengths of the BHE to be drilled can become, in these contexts, as high as 19 times the length needed with common antifreeze solutions such as PG25\%. Using PG 33\% to lower the minimum temperature constraint is convenient only in heating-dominated buildings. Using $\mathrm{CaCl}_{2}$ as an antifreeze additive reduces lifetime costs, especially for cold climates, since it allows to reduce BHE lengths with a negligible additional cost for the antifreeze additive. 
Even if the use of water as a heat carrier fluid can be a questionable choice from an economic point of view, it generally leads to a reduction of GHG emissions compared to the standard PG25\%, with the exception of largely heating-dominated buildings (i.e., Stockholm and some cases in Berlin). Indeed, drilling BHEs has an appraisable carbon footprint (estimated in $25.61 \mathrm{~kg} \mathrm{CO}_{2}$ eq. per meter of probe) and, hence, the substantial increase of BHE length needed in very cold climates to avoid using antifreeze additives impacts the life cycle carbon footprint. Using $\mathrm{CaCl}_{2} 20 \%$ as a heat carrier fluid always leads to a reduction of GHG emissions compared to PG25\% and, in the most heating-dominated cases, it is the least carbon-intensive choice.

Results therefore highlighted that calcium chloride can be an optimal solution in many situations, as it offers both an economic and performance benefit compared to propylene glycol. The corrosion issues, however, still need to be solved to allow its massive application.

This research provided a large-scale analysis of the impact of different choices for the heat carrier fluid of BHEs. Further research should focus on the monitoring on real-world installations of the technical issues highlighted in this paper, such as the energy consumption of the heat pump and the ground-side circulation pump with different fluids.

Supplementary Materials: The following are available online at http://www.mdpi.com/1996-1073/13/21/5653/s1. Table S1. Heating, cooling and DHW thermal loads: monthly total demand (kWh) and peak load (kW). Table S2. BHE sizing: number and depth of boreholes resulting from the sizing procedure on EED. Table S3. Monthly energy demands $(\mathrm{kWh})$ of the heat pump and the ground-side circulation pump. Table S4. Life cycle costs $(€$ in 25 years) of borehole drilling and installation, heat pump and ground-side circulation pump operation, and fluid replacement. Table S5. Carbon footprint ( $\mathrm{kg} \mathrm{CO}_{2}$ eq. in 25 years) of borehole drilling and installation, heat pump and ground-side circulation pump operation, and fluid replacement.

Author Contributions: Conceptualization, methodology, software, writing-original draft preparation, writing-review and editing: N.B., A.C., C.B. and R.S. All authors have read and agreed to the published version of the manuscript.

Funding: This research received no external funding.

Acknowledgments: The authors gratefully acknowledge the valuable contribution of Sofia Credaro, who assisted in the proofreading and language editing of the manuscript.

Conflicts of Interest: The authors declare no conflict of interest.

\section{Glossary}

$\begin{array}{ll}\text { Acronyms } & \\ \text { BHE } & \text { Borehole heat exchanger } \\ \text { CDD } & \text { Cooling degree-days } \\ \text { DHW } & \text { Domestic hot water } \\ \text { EED } & \text { Earth Energy Designer } \\ \text { EG } & \text { Ethylene glycol } \\ \text { GHG } & \text { Greenhouse gas } \\ \text { GSHP } & \text { Ground-source heat pump } \\ \text { HDD } & \text { Heating degree-days } \\ \text { PG } & \text { Propylene glycol } \\ \text { RfD } & \text { Chronic reference dose } \\ \text { Latin letters } & \\ A & \text { Calibration coefficient for the dynamic viscosity (Pa·s) } \\ B & \text { Calibration coefficient for the dynamic viscosity }\left({ }^{\circ} \mathrm{C}^{-1}\right) \\ C_{C P} & \text { Energy demand of the ground-side circulation pump }(\mathrm{kwh}) \\ C_{H P} & \text { Energy demand of the heat pump }(\mathrm{kwh}) \\ C O P_{D H W} & \text { Monthly value of the coefficient of performance for heating (dimensionless) } \\ C O P_{h} & \text { Monthly value of the coefficient of performance for DHW (dimensionless) } \\ D & \text { Pipe diameter (m) } \\ E E R & \text { Monthly value of the energy efficiency ratio for cooling (dimensionless) } \\ g & \text { Gravity acceleration }\left(9.81 \mathrm{~m} / \mathrm{s}^{2}\right)\end{array}$




$\begin{array}{ll}J & \text { Friction loss gradient (dimensionless) } \\ L & \text { Total BHE pipe length (m) } \\ Q_{c} & \text { Building-side cooling demand (kwh) } \\ Q_{c, \text { ground }} & \text { Ground-side cooling demand (kwh) } \\ Q_{D H W} & \text { Building-side domestic hot water demand (kwh) } \\ Q_{D H W, \text { ground }} & \text { Ground-side domestic hot water demand (kwh) } \\ Q_{h} & \text { Building-side heating demand (kwh) } \\ Q_{h, \text { ground }} & \text { Ground-side heating demand (kwh) } \\ R_{a} & \text { Internal borehole thermal resistance (mk/W) } \\ R_{b} & \text { Borehole thermal resistance (mk/W) } \\ S P F_{c} & \text { Seasonal performance factor for cooling (dimensionless) } \\ S P F_{D H W} & \text { Seasonal performance factor for domestic hot water (dimensionless) } \\ S P F_{h} & \text { Seasonal performance factor for heating (dimensionless) } \\ T_{f} & \left.\text { Mean fluid temperature between inlet and outlet of the BHE ( }{ }^{\circ} \mathrm{C}\right) \\ t_{f u n c} & \text { Operational time of the ground-side circulation pump (h) } \\ V_{f} & \left.\text { Fluid flow rate per each BHE U-pipe (m }{ }^{3} / \mathrm{s}\right) \\ G r e k \text { letters } & \\ \eta & \text { Energy efficiency of the ground-side circulation pump (dimensionless) } \\ \lambda_{0} & \text { Normalized friction loss (dimensionless) } \\ \mu_{f} & \text { Dynamic viscosity of the heat carrier fluid (Pa.s) } \\ \rho_{f} & \text { Fluid density (kg/m }{ }^{3} \text { ) }\end{array}$

\section{References}

1. Sanner, B. Summary of EGC 2019 Country Update Reports on Geothermal Energy in Europe. Available online: https://bit.ly/39ktzFU (accessed on 6 February 2020).

2. Antics, M.; Bertani, R.; Sanner, B. Summary of EGC 2013 Country Update Reports on Geothermal Energy in Europe. Available online: https://bit.ly/3m149TJ (accessed on 6 February 2020).

3. Kavanaugh, S.P.; Rafferty, K.D. Geothermal Heating and Cooling: Design of Ground-Source Heat Pump Systems; ASHRAE: Atlanta, GA, USA, 2014; ISBN 1-936504-85-5.

4. Regione Lombardia Registro Sonde Geotermiche (Regional Register of Borehole Heat Exchangers). Available online: http://www.rinnovabililombardia.it/opendata (accessed on 11 September 2020).

5. Casasso, A.; Sethi, R. Assessment and Minimization of Potential Environmental Impacts of Ground Source Heat Pump (GSHP) Systems. Water 2019, 11, 1573. [CrossRef]

6. Saner, D.; Juraske, R.; Kübert, M.; Blum, P.; Hellweg, S.; Bayer, P. Is it only $\mathrm{CO}_{2}$ that matters? A life cycle perspective on shallow geothermal systems. Renew. Sustain. Energy Rev. 2010, 14, 1798-1813. [CrossRef]

7. Prestor, J.; Pestotnik, S.; Zosseder, K.; Böttcher, F.; Capodaglio, P.; Götzl, G.; Bottig, M.; Weilbold, J.; Maragna, C.; Martin, J.-C.; et al. Overview and Analysis of Regulation Criteria and Guidelines for NSGE Applications in the Alpine Region. GRETA Project Deliverable 2.1.1. Available online: http://bit.ly/2S8mMGy (accessed on 10 June 2020).

8. Zhu, K.; Fang, L.; Diao, N.; Fang, Z. Potential underground environmental risk caused by GSHP systems. Procedia Eng. 2017, 205, 1477-1483. [CrossRef]

9. Galloway, L.; Dolislager, F.; Stewart, D.; Noto, K.; Manning, K. The Risk Assessment Information System (RAIS). Available online: https://rais.ornl.gov/ (accessed on 24 June 2019).

10. Bucci, A.; Prevot, A.B.; Buoso, S.; De Luca, D.A.; Lasagna, M.; Malandrino, M.; Maurino, V. Impacts of borehole heat exchangers (BHEs) on groundwater quality: The role of heat-carrier fluid and borehole grouting. Environ. Earth Sci. 2018, 77, 175. [CrossRef]

11. Lissner, H.; Wehrer, M.; Reinicke, M.; Horváth, N.; Totsche, K.U. Constraints of propylene glycol degradation at low temperatures and saturated flow conditions. Environ. Sci. Pollut. Res. 2014, 22, 3158-3174. [CrossRef] [PubMed]

12. Schotanus, D.; Meeussen, J.C.L.; Lissner, H.; Van Der Ploeg, M.J.; Wehrer, M.; Totsche, K.U.; Van Der Zee, S. Transport and degradation of propylene glycol in the vadose zone: Model development and sensitivity analysis. Environ. Sci. Pollut. Res. 2013. [CrossRef] [PubMed] 
13. OECD. OECD Screening Information Data Set (SIDS) on Calcium Chloride. Available online: http: //bit.ly/CaCl2_OECD (accessed on 5 June 2020).

14. Dalla Santa, G.; Farina, Z.; Anbergen, H.; Rühaak, W.; Galgaro, A. Relevance of computing freeze-thaw effects for borehole heat exchanger modelling: A comparative case study. Geothermics 2019, 79, 164-175. [CrossRef]

15. Erol, S.; François, B. Freeze damage of grouting materials for borehole heat exchanger: Experimental and analytical evaluations. Geomech. Energy Environ. 2016, 5, 29-41. [CrossRef]

16. Casasso, A.; Ferrantello, N.; Pescarmona, S.; Bianco, C.; Sethi, R. Can borehole heat exchangers trigger cross-contamination between aquifers? Water 2020, 12, 1174. [CrossRef]

17. Department of Energy Solar Water Heating System Maintenance and Repair. Available online: https: //bit.ly/32XDPCP (accessed on 27 July 2020).

18. Casasso, A.; Sethi, R. Efficiency of closed loop geothermal heat pumps: A sensitivity analysis. Renew. Energy 2014, 62, 737-746. [CrossRef]

19. Casasso, A.; Sethi, R. Sensitivity Analysis on the Performance of a Ground Source Heat Pump Equipped with a Double U-pipe Borehole Heat Exchanger. Energy Procedia 2014, 59, 301-308. [CrossRef]

20. Hellstrom, G.; Sanner, B. Earth Energy Designer, User Manual Version 2.0. 2000. Available online: https://www.buildingphysics.com/manuals/eed.pdf (accessed on 25 September 2019).

21. Rivoire, M.; Casasso, A.; Piga, B.; Sethi, R. Assessment of Energetic, Economic and Environmental Performance of Ground-Coupled Heat Pumps. Energies 2018, 11, 1941. [CrossRef]

22. Repubblica Italiana Decreto Interministeriale 26 Giugno 2015-Allegato B (Interministerial Decree 26 June 2015-Annex B). Available online: https://bit.ly/31AH3mJ (accessed on 11 February 2020).

23. Ballarini, I.; Corgnati, S.P.; Corrado, V. Use of reference buildings to assess the energy saving potentials of the residential building stock: The experience of TABULA project. Energy Policy 2014, 68, 273-284. [CrossRef]

24. Corrado, V.; Ballarini, I.; Corgnati, S.P. National Scientific Report on the TABULA Activities in Italy. Available online: http://bit.ly/TABULA_IT (accessed on 10 January 2020).

25. ASHRAE. Handbook-Fundamentals; ASHRAE: Atlanta, GA, USA, 2013.

26. Eskilson, P. Thermal Analysis of Heat Extraction Boreholes. Available online: http://bit.ly/2JCl6Be (accessed on 6 October 2019).

27. VDI VDI 4640 Sheet 2. Thermal Use of the Underground-Ground Source Heat Pump Systems. Available online: http://bit.ly/30z50zm (accessed on 6 October 2019).

28. Hellstrom, G. Ground Heat Storage, Thermal Analyses of Duct Storage Systems. Ph.D. Thesis, University of Lund, Lund, Sweden, 1991. Available online: http://bit.ly/Hellstrom (accessed on 19 October 2020).

29. Bennet, J.; Claesson, J.; Hellstrom, G. Multipole Method to Compute The Conductive Heat Flows to and between Pipes in a Composite Cylinder; Lund University Publications: Lund, Sweden, 1987.

30. Clivet. Clivet WSHN-XEE2-MF Water-Water Heat Pumps. Technical Bulletin. Available online: http: //bit.ly/WSHN-XEE2-MF (accessed on 30 September 2020).

31. Priarone, A.; Silenzi, F.; Fossa, M. Modelling Heat Pumps with Variable EER and COP in EnergyPlus: A Case Study Applied to Ground Source and Heat Recovery Heat Pump Systems. Energies 2020, 13, 794. [CrossRef]

32. Eurostat Electricity Price Statistics. Available online: http://bit.ly/2LUlFen (accessed on 14 December 2018).

33. IPCC Fifth Assessment Report AR5. Available online: http://bit.ly/IPCC_AR5 (accessed on 7 March 2020).

34. Hildebrand, J.; Srocka, M.; Ciroth, A. OpenLCA. Available online: http://www.openlca.org/ (accessed on 11 March 2019).

35. ISPRA Fattori di Emissione Atmosferica di CO2 e Altri Gas a Effetto Serra Nel Settore Elettrico (CO2 Emission Factors of the Electric Sector). Available online: http://bit.ly/ISPRA_EF (accessed on 2 February 2020).

Publisher's Note: MDPI stays neutral with regard to jurisdictional claims in published maps and institutional affiliations. 